\title{
Obstructive Sleep Apnea Syndrome in a Railroad Controller Worker
}

\author{
AGRIPINA RASCU ${ }^{1}$, LAURA MOISE ${ }^{2}$, EUGENIA NAGHI ${ }^{1}$, ALEXANDRA RASCU $^{3}$, LAVINIA LACATUSU ${ }^{2}$ \\ 1"Carol Davila" University of Medicine and Pharmacy, Occupational Medicine Department \\ ${ }^{2}$ "Colentina" Hospital, Occupational Medicine Department, Bucharest, Romania \\ 3"Elias" Emergency University Hospital, Bucharest, Romania
}

\begin{abstract}
Sleep Apnea Syndrome (SAS) constitutes a healthcare issue of major importance at international level with a prevalence of $5 \%$ in the active population. Consequentially to the induced co-morbidities, the mortality reaches as high as $39 \%$ at eight years time lapse from the initial diagnostic. Seldom undiagnosed, the severity spectrum of SAS, in the absence of therapy, only continues to amplify.

Here below, we are presenting the case of a 49 years old patient, railroad controller worker, non-smoker and occasionally alcohol user, who was hospitalized in our Clinic for Occupational Medicine. During last year, the patient was accusing excessive daytime somnolence, breath arrests during sleep, intense snoring, morning headaches, morning oral dryness, pin point chest pain, nocturia (4-5 nocturnal urination), concentration difficulties and an overall reduced work capacity. The presumptive diagnostic of Obstructive Sleep Apnea is being considered based on the correlation between the clinical presentation and the Epworth, Stanford and Berlin questionnaire results. The key diagnostic element was the polygraph recording over an 8 hours sleep period. Positive Diagnosis: Obstructive Sleep Apnea severe form. Management and recommendations: (1) Behavioral therapy (weight loss) and (2) CPAP (Continuous Positive Airway Pressure) therapy which was instituted immediately after the positive diagnosis was made. As a consequence, the respiratory symptoms, the frequent episodes of daytime snoozing and the concentration difficulties at work place diminished considerably.
\end{abstract}

Key words: sleep apnea syndrome, railroad controller, polygraph, work accident.

Sleep Apnea Syndrome, a complex entity, insufficiently known and therefore under diagnosed in Romania, is characterized by: (1) the complete interruption (apnea) or the reduction of the respiratory flow (hypopnea) during sleep time [1].

Apnea is defined as the complete arrest of the respiratory flow over a period of 10 seconds or more, while hypopnea is defined as: $>50 \%$ reduction in breathing amplitude, or $<50 \%$ in breathing amplitude from the baseline flow if associated with: (1) an oxygen desaturation $\left(\mathrm{SaO}_{2}\right)$ level of at least $3 \%$, or with (2) at least one micro arousal during sleep time (Chicago Criteria 1999).

According to the International Classification of Sleep Disorders (ICSDII) [2] - there are three types of sleep apnea: obstructive, central and mixed.

The Obstructive Sleep Apnea Syndrome (OSAS) is defined as a clinical syndrome that is manifested by recurrent episodes of upper airway obstruction, which leads to the reduction (hypopnea) or the stopping (apnea) of the oro-nasal airflow, and associates increased respiratory effort and intermittent decreased arterial oxygen saturation [3].
SASO is accompanied by excessive daytime sleepiness (EDS) and therefore, increases the risk of work accidents by decreased ability to concentrate, and increases also the risk of road accidents due to falling asleep at the wheel.

Here below we are presenting the case of a 49 years old patient, railroad controller worker, with typical picture of Sleep Apnea Syndrome, which mentions daily performances alteration by the occurrence of memory, attention and concentration disorders.

\section{CASE PRESENTATION}

We present a 49 years years old patient, railroad controller worker, non-smoker and occasionally alcohol user, who was hospitalized in the Occupational Medicine Clinic.

From his medical history, we remind: metabolic syndrome (obesity, dyslipidemia, hypertension, type II diabetes), ischemic heart disease, an episode of paroxysmal atrial fibrillation, drug converted after 6 months. He is under treatment 
with oral antidiabetics, diuretics and beta blockers. Clinical examination reveals abdominal and trunk obesity (BMI: $38.45 \mathrm{~kg} / \mathrm{m}^{2}$ ), neck circumference: $50 \mathrm{~cm}$, waist circumference: $148 \mathrm{~cm}$, vultuos facies, macroglossia (Mallampati score III). He mentions that in the past 2 years, he has gained weight, up to $15 \mathrm{~kg}$, TA $=150 / 100 \mathrm{mmHg}$.

The patient has been working for 20 years in the same job. He is a railroad controller worker at CFR and his job activity is in a train station. He works in alternative shift works, the work is monotonous and requires monitoring and providing trains entering and leaving the station: signals the train mechanics if they have to stop or go without stopping in the station, directs and controls the activities related to the wagons and/or platforms assembly maneuvers in forming trains. He supervises control panels, relays and safety systems. He also deals with the computerized control of safety and rail traffic operating systems.

From approximatively one year, he charges excessive daytime somnolence, breath arrest during sleep, intense snoring, morning headaches, morning oral dryness, pin point chest pain, nocturia (4-5 nocturnal urination), concentration difficulties and an overall reduced work capacity. Over the past 3 months, complaints have increased, the patient saying that, to keep him awake at work, he had to improvise a method through which he could wake up whenever he fell asleep (and put on his desk a stack of books which he was hitting whenever he was falling asleep).

On its own initiative, he came to the Occupational Medicine Clinic, where, for the first time, it was raised the suspicion of sleep apnea syndrome. For diagnosis, the first step was evaluating the presence of excessive daytime sleepiness using screening questionnaires: (a) Stanford Sleepiness Scale (resulting 6 of 7 possible points), (b) Epworth questionnaire (outcome 19 of 24 points maximum) and (c) Berlin Questionnaire (result 3 of 3 points) indicating a high positive predictive value for the diagnosis of SAS. Because the key diagnostic element is the printing registration, we mounted the patient a polygraph machine during the night (SOMNO check Effort, 2005 Weinmann, Germany), which, over an 8 hours period, recorded the following parameters: air flow, thoracic and abdominal respiratory efforts, snoring, oxygen saturation of blood pressure, heart rate and body position (Fig. 1).

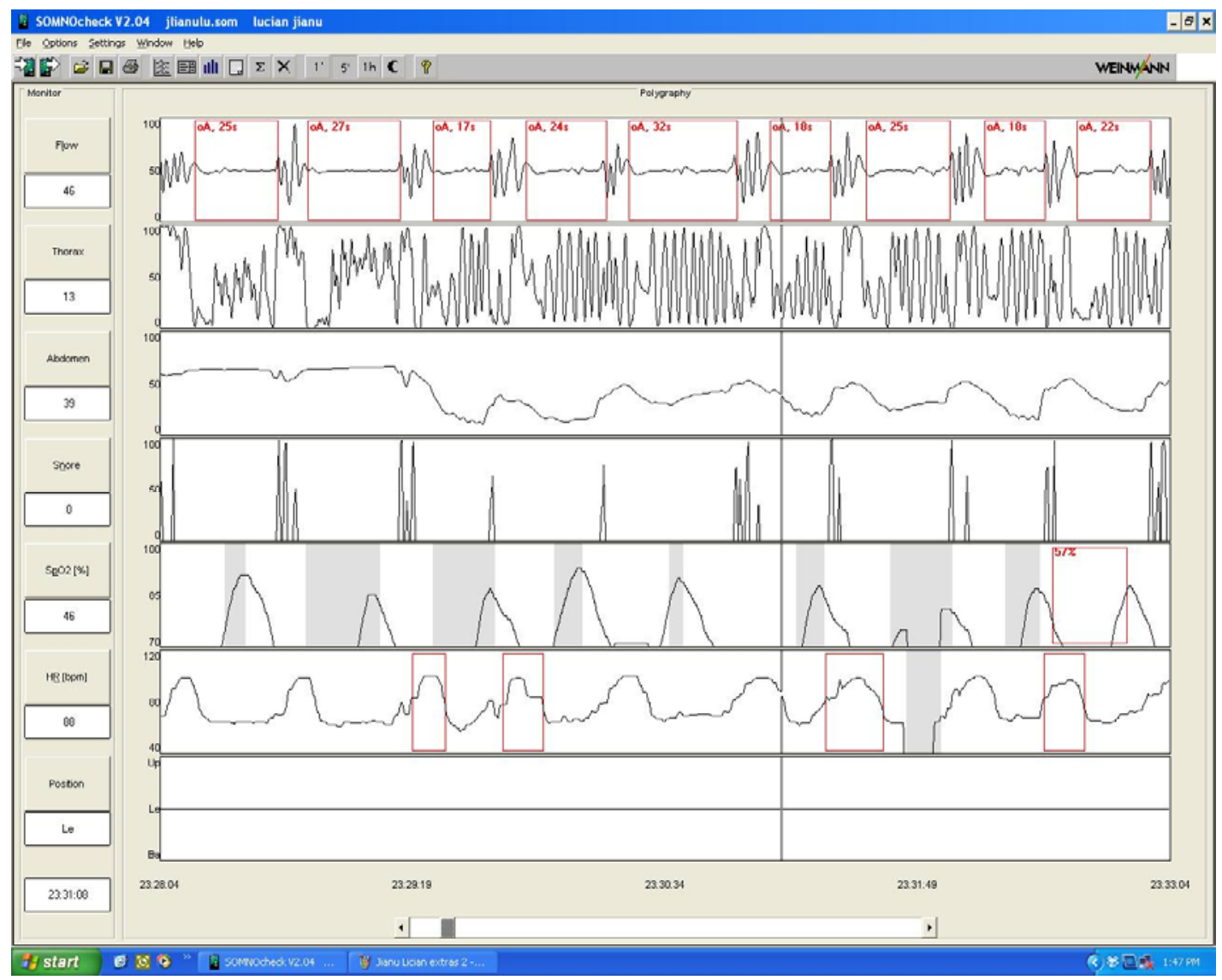

Figure 1. Polygraphic recording: J.L, a 49 years old man. 


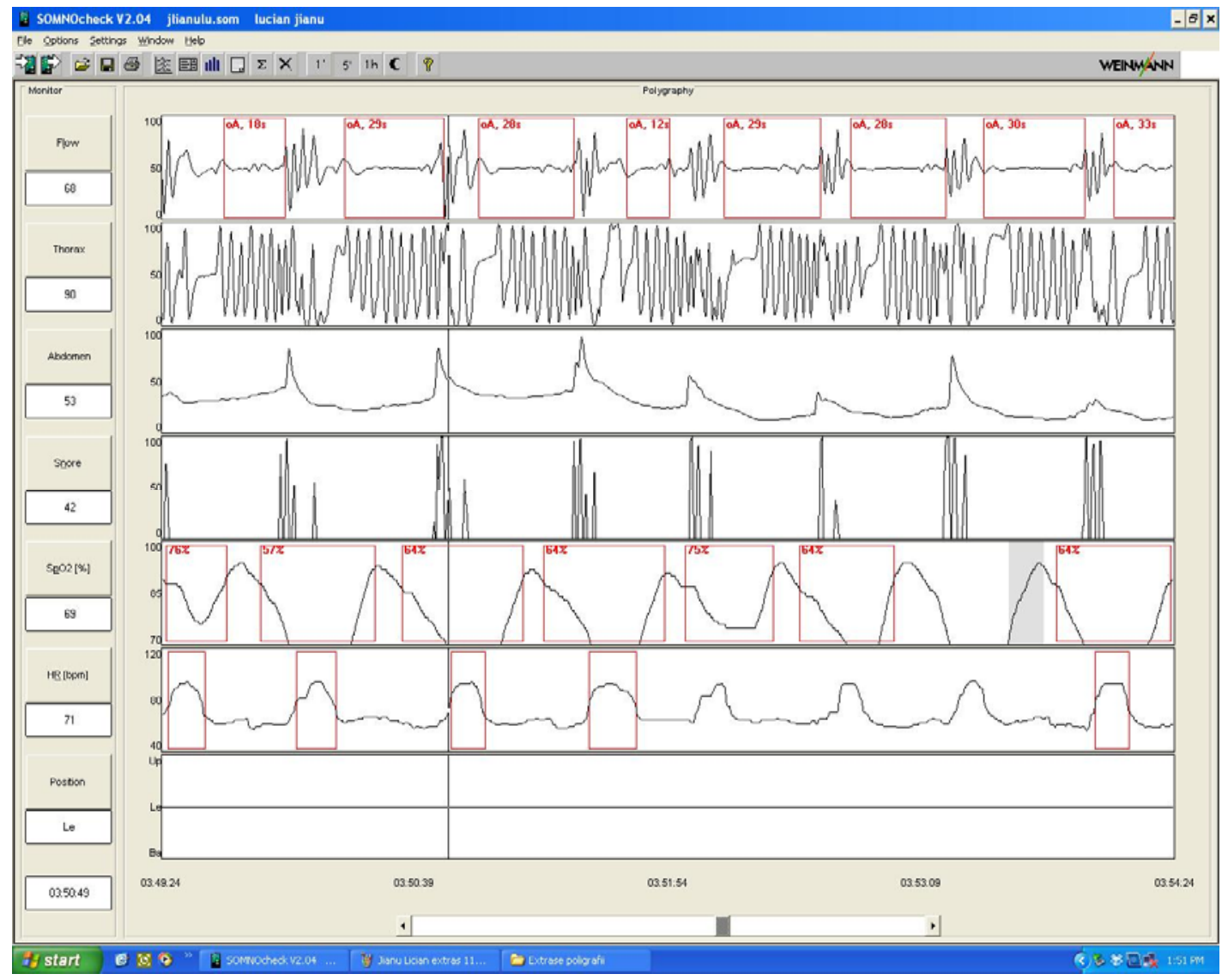

Figure 2. Nocturnal polygraphic recording for 5 minutes: episodes of obstructive apnea, with duration between 12-33 seconds, desaturations - the lowest value was $57 \%$, variations of the cardiac rhythm.

Distribution of apnea events

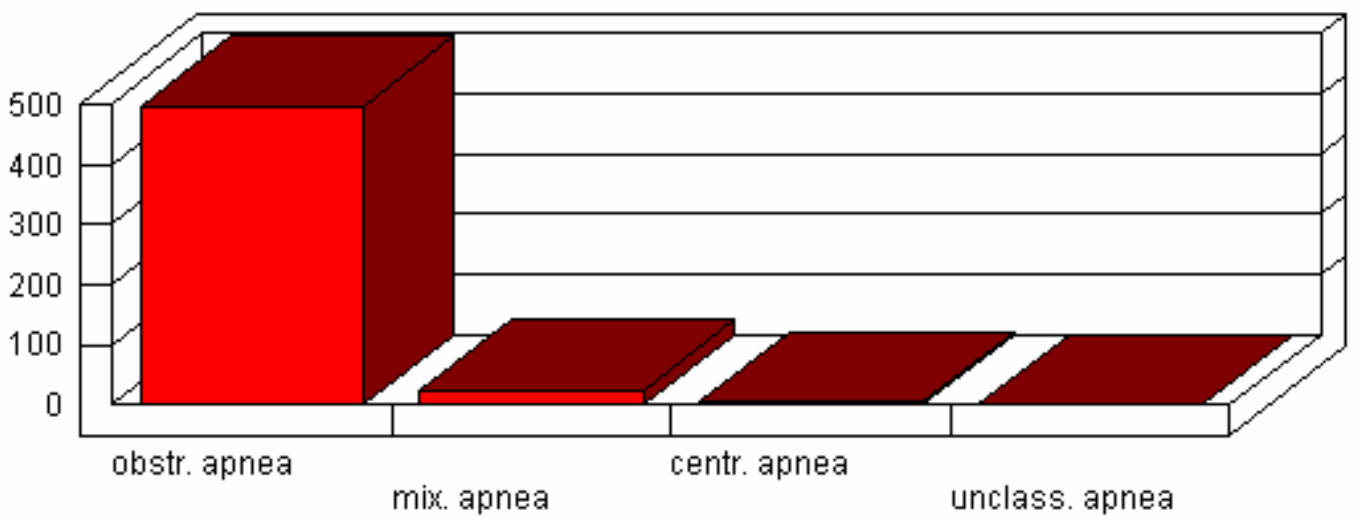

Figure 3. Distribution of apnea events during 8 hours of recording. The episodes number of obstructive apnea is majoritary (521 episodes).

The nocturnal polygraphic recording showed numerous episodes of obstructive apnea, characterized by the absence of the oronasal air flow with the persistence of the thoracoabdominal respiratory movements. It also showed some episodes of central apnea, characterized by the absence of the oronasal flow, accompanied by the absence of the thoracoabdominal respiratory movements, conseq- uences of the respiration and inervation stopping of the muscles involved in breathing through central mechanism, intermittent snoring and frequent desaturation.

The recording result was manually validated and it was made a report that included data about: apnea/hypopnea index (AHI), desaturation index, the duration and medium value of them, snoring, 
the variability of the heart rate. Thus, the recorded results: (1) the apnea/hypopnea index (represents the number of apneas and hypopneas recorded in one hour of sleep) $=\mathbf{8 5}$ events/hour, the medium duration of an event was 27 seconds; (2) 521 episodes of obstructive apnea and 25 episodes of mixed apnea; (3) the desaturation index: 78 episodes/ hour, the lowest value of the desaturation was $46 \%$ and (4) frequent variation of the heart rate.

Validated by the track recording, the positive diagnosis made was: Obstructive Sleep Apnea Syndrome.

American Sleep Disorders Association together with American Thoracic Society and European Respiratory Society suggested a standardized definition for OSAS: the presence of at least 5 episodes of apnea or hypopnea with respiratory effort related arousal (RERA)/sleep-hour associated with excessive daytime somnolence, or with two or more of the following symptoms: heavy snoring, "gasping" during sleep time, recurrent nocturnal arousals, non-refreshing sleep, daytime fatigue, lack of concentration [2].

The severity of the syndrome correlates directly with the frequency of apnea-hypopnea episodes per sleep-hour. Thus: [4]

- light OSAS is characterized by AHI $>5$ $<15$ events/sleep-hour

- moderate OSAS - when AHI is $>15$ but $<$ 30 events/sleep-hour

- severe OSAS - when AHI is > 30 events/ sleep-hour

Based on the above criteria the final diagnosis of the patient was: Severe Obstructive Sleep Apnea Syndrome.

The treatment recommendations were: (1) Behavioral therapy: weight loss and (2) CPAP (continuous positive airway pressure) therapy in the automated mode 9-12-15 $\mathrm{cm} \mathrm{H}_{2} \mathrm{O}$, at $10 \mathrm{~min}$ ramping intervals.

CPAP is a device providing continuous positive pressure airflow to the respiratory airways through a system of mask, valves and tubes. Its role is to maintain open the upper respiratory airways during sleep time, preventing the apnea/ hypopnea episodes, the arousals and desaturations occurring throughout all the sleep stages.[5]

From the very first night of using CPAP, the patient reported an improvement in the sleep quality. Evaluation after 3 months of CPAP usage evidenced a very good evolution: the residual AHI being only 11 events/sleep-hour.

\section{DISCUSSION}

Sleep is an important component of life. The quality and duration of sleep are determining factors for the well being and the overall quality of life, while sleep disturbances lead to health deterioration and reduction of the cognitive function [6].

Most frequent sleep disturbances are insomnia, OSAS and "restless legs" syndrome (RLS).

OSAS is the most common type of sleep apnea worldwide, populational studies estimating its prevalence at $3-7 \%$ in the adult male population and respectively $2-5 \%$ in the female population for the 30-60 years age bracket $[6,7]$.

The behavioral changes and sleep fragmentation induced by OSAS alter the life quality of the individual leading to excessive daytime somnolence and subsequently to a reduction of the concentration capacity, cognitive performance, speed of reaction, etc. Consequence of OSAS, the excessive daytime somnolence constitutes a problem of general interest especially when the affected people work in fields of activity where the decisions and/or the professional activity can be dangerous or have direct influence over other people's lives. Literature data suggests a significant association between OSAS and the increased risk of work related and traffic accidents signaling the legal implications of OSAS. Based on these informations, starting from 1997, the ERS (European Respiratory Society) has officially stated the importance of monitoring the consequences of excessive daytime somnolence for public safety [8].

On long term, the induced hypoxemia, the intermittent re-oxygenation and the hypercapnia occurring during the apnea/hypopnea episodes plus the arousals further fragmenting the sleep, generate an over activation of the sympathetic drive, systemic inflammation, oxidation stress, endothelial dysfunction, increased insulin resistance. All these and more are pathological foundations involved in the appearance of cardiovascular (systemic hypertension, pulmonary hypertension, ischemic heart disease, arrhythmias and cardiovacular events) and metabolic (diabetes mellitus, obesity, etc) comorbidities [1,9].

Due to the reduced rate of OSAS recognition, only a small fraction of patients are diagnosed and treated. In its conclusions, the Sleep Heart Health Study stated that, although the OSAS prevalence was greater than $4 \%$, only $1.6 \%$ of these patients were diagnosed and only $0.6 \%$ were treated [10].

We presented a case of severe OSAS in a railroad controller worker, whose life quality was reduced, not only by the excessive daytime 
somnolence, but also by the range of associated comorbidities (hypertension, arrhythmias, DM2, obesity). Consequently, the progressive reduction of daily performance represented in this case an important risk and danger for the public safety. We have to underline the fact that the patient presented to the hospital by himself, worried by the increasing difficulty to fulfill his work duties and responsibilities.

After establishing the diagnosis, the patient started the CPAP therapy. Three months later the patient exhibited a $4 \mathrm{~kg}$ weight loss, the reduction of respiratory symptoms and a considerable diminution of daytime snoozing episodes and concentration difficulties.

This case presentation raises an issue that can be approached from two distinct directions: (1) case identification, diagnosis and medical management and (2) creation of interventional strategies in general population and more so in employees.

Screening for excessive daytime somnolence and implicitly for OSAS should be part of the routine anamnestic questionnaire in all occupational medicine evaluations and controls. This takes into consideration the fact that OSAS represents a significant cause for work related and traffic accidents, for chronic illnesses and increased absenteeism.

The OSAS diagnosis involves (1) symptom evaluation by use of specific standardized questionnaires targeting excessive daytime somnolence,
(2) clinical exam, (3) recording the respiratory sleep events initially by polygraphy, completed later on by polysomnography, whenever the polygraphic results are not conclusive.

Sleep disturbances are increasingly frequent in general population and the healthcare workers need to direct the patients with presumtive OSAS diagnosis to specialized centers for correct evaluation and treatment. This also underlines the role of Occupational Medicine specialist for a timely and early diagnosis and treatment of OSAS through periodic routine medical exams in all employees, regardless of field of activity.

\section{CONCLUSION}

The purpose of ths article is to underline the need for OSAS diagnosis and the importance of initiating an early adequate treatment in all patients working in fields of activity with impact or influence on other human lives. It is important to mention that missing the OSAS diagnosis can have dramatic consequences. With a prevalence reaching $5 \%$ in the active population [11] and a mortality, which in the absence of treatment, can get as high as $39 \%$ eight years from diagnosis due to involved comorbidities, OSAS is clearly a significant healthcare problem of worlwide importance.

Sindromul de apnee în somn (SAS) reprezintă o problemă importantă de sănătate la nivel mondial, cu o prevalență de 5\% in populația activă. Ca o consecință a comorbidităților pe care le determină mortalitatea atinge 39\% în 8 ani de la stabilirea diagnosticului, dacă nu se instituie tratamentul. Pentru că cel mai adesea rămâne nediagnosticat, spectrul severității SAS se amplifică.

Prezentăm cazul unui pacient în vârstă de 49 de ani, de profesie dispecer de siguranță feroviară, nefumător şi consumator ocazional de alcool, care s-a prezentat pentru internare în Clinica de Medicină a Muncii. De aproximativ un an, acuză somnolență diurnă excesivă, oprirea respirației în timpul somnului, sforăit intens, cefalee matinală, senzație de gură uscată la trezire, precordialgii cu caracter de ințepătură, nicturie (4-5 micțiuni nocturne), dificultăți de concentrare şi scăderea capacității de muncă. S-a suspicionat sindrom de apnee obstructivă în somn (SASO) corelând tabloul simptomatic cu rezultatele chestionarelor Epworth, Stanford şi Berlin. Elementul cheie de diagnostic a fost înregistrarea poligrafică, pe o perioadă de 8 ore de somn. Diagnosticul pozitiv: sindrom de apnee în somn de tip obstructiv - formă severă. I s-a recomandat: (1) tratament comportamental (scădere în greutate) şi (2) terapie cu CPAP (Continuous Positive Airway Pressure). După diagnosticare, pacientul a început terapia CPAP. Atât simptomatologia respiratorie, cât şi episoadele de ațipire şi dificultățile de concentrare la locul de muncă s-au diminuat considerabil. 


\section{REFERENCES}

1. MIHALTAN F. Sindromul de apnee în somn. Medicină Internă, edited by Gherasim L, Ed. Medicală, București: 2001; 599-619.

2. AMERICAN ACADEMY OF SLEEP MEDICINE. International Classification of Sleep Disorders ICSD $2^{\text {nd }}$. Diagnostic and coding manual $2^{\text {nd }}$ ed. Westchester, L : 2005.

3. TODEA D, ROSCA L. Sindromul de apnee în somn de tip obstructiv. In: Apneea în somn şi comorbiditățile sale. Edited by Doina Adina Todea, Ed. Medicală Universitară “Iuliu Hațieganu” Cluj-Napoca: 2013;10.

4. YAGGI H, KINGMAN PS. Adult Obstructive Sleep Apnea/Hypopnea Syndrome: Definitions, risk factors and pathogenesis. Clin. Chest Med. :2010; 31; 180-186.

5. MORGENTHALER TI, BROWN T, ZAK R, SWICK TJ. Standards of Practice Committee of the AASM. Practice parameters for the use of autotitrating continuous positive airway pressure devices for titrating pressures and treating adult patients with OSAS. Sleep, 2008; 31(1); 141-148.

6. GIMBADA BM, RODENSTEIN D. Medicolegal and economic aspects of sleep disorders. ERS hanbook respiratory sleep medicine, 2012; 189-195.

7. LINDBERG E. Epidemiology of OSA. European Respiratory Monograph, 2010; 23-36.

8. NICHOLAS WT, KRIEGER J. Public Health and Medicolegal Implication of Sleep Apnea. ERJ 2002; 20; 1594-1609.

9. FOSTER GD, SANDERS MH, MILLMAN R. Sleep AHEAD Research Group: Obstructive Sleep Apnea Among Obese Patients With Type 2 Diabetes. Diabetes Care 2009; 32; 1017-1019.

10. KAPUR V, STROHL KP, REDLINE S. Underdiagnosis of sleep apnea syndrome in U.S. communities. Sleep Breath 2002; 6:49-54.

11. MIHALTAN F. Sindromul de apnee in somn. In: Pneumologie edited by BODAN MA, ed. Universitară "Carol Davila", Bucureşti; 2008; 443-454.

Received January 25, 2015 